\title{
PRINCÍPIOS CONSTITUCIONAIS E OS ALIMENTOS GRAVÍDICOS
}

\section{Fernanda Mendes Francisco dos Santos ${ }^{1}$ \\ Denise Passos da Costa Plínio² \\ Mauricio Martins Alves ${ }^{3}$}

Resumo: O presente artigo analisa os alimentos gravídicos, enquanto uma garantia derivada do princípio da dignidade da pessoa humana. A Lei 11.804, de 05, de novembro, de 2008, enquanto uma proteção à maternidade e ao nascituro permite à mulher gestante receber pensão no decorrer da gestação, em espécie ou em alimentos. A partir da análise de jurisprudência e de doutrina correlata defende que, fundamentada nesta dignidade, garante os cuidados necessários para o bem-estar da gestação mesmo sem comprovação formal da paternidade, bastando à gestante apresentar "indícios contundentes dela".

Palavras-chave: Alimentos gravídicos; Princípios constitucionais; Maternidade; Nascituro; Paternidade.

\footnotetext{
${ }^{1}$ Faculdade de Direito/Universidade do Vale do Paraíba, Brasil. E-mail: reginaldonds46@gmail.com.

2 Faculdade de Direito/Universidade do Vale do Paraíba, Brasil. E-mail: dplinio@univap.br.

3 Faculdade de Direito/Universidade do Vale do Paraíba, Brasil. E-mail: mmalves@univap.br.
} 